\title{
有機-無機ハイブリッド分子による生体防御系の活性化
}

\author{
藤江智也, ${ }^{a}$ 中 寛史, ${ }^{b, c}$ 山本千夏, ${ }^{b, d}$ 新開泰弘, ${ }^{e}$ 熊谷嘉人, ${ }^{e}$ 鉣冶利幸 $*, a, b$
}

\section{Activation of Cellular Defense Mechanism by Organic-Inorganic Hybrid Molecules}

\author{
Tomoya Fujie, ${ }^{a}$ Hiroshi Naka, ${ }^{b, c}$ Chika Yamamoto, ${ }^{b, d}$ Yasuhiro Shinkai, ${ }^{e}$ \\ Yoshito Kumagai, ${ }^{e}$ and Toshiyuki Kaji ${ }^{*}, a, b$ \\ ${ }^{a}$ Faculty of Pharmaceutical Sciences, Tokyo University of Science; ${ }^{b}$ Research Institute for Science and \\ Technology, BOM, Tokyo University of Science; 2641 Yamazaki, Noda, Chiba 278-8510, Japan: \\ 'Research Center for Materials Science, Nagoya University; Furo-cho, Chikusa-ku, Nagoya

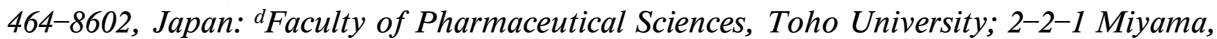 \\ Funabashi, Chiba 274-8510, Japan: and ${ }^{e}$ Graduate School of Comprehensive Human \\ Sciences, University of Tsukuba; 1-1-1 Tennodai, Tsukuba, Ibaraki 305-8575, Japan.
}

(Received January 30, 2014)

\begin{abstract}
Organic-inorganic hybrid molecules can exhibit biological activities by controlling the activities of their individual components. These molecules can be applied as seed/lead compounds in drug development, and can be used as molecular probes in chemical biology for the elucidation of the molecular mechanisms of biological systems. In this review, we introduce copper diethyldithiocarbamate (Cu10), a copper complex, as a compound that activates nuclear factor erythroid 2-related factor 2 (Nrf2) and induces metallothionein, which are the key cellular defense factors against toxic metals and oxidative stress in vascular endothelial cells. It was found that neither the complexes with the same ligand and other metal ions (including zinc and iron) nor the ligand alone was inactive. Therefore, both copper ion and the ligand of $\mathrm{Cu} 10$ are essential components for the biological functioning of the complex. In addition, Cu10 may be useful in clarifying the molecular mechanism underlying metallothionein induction in vascular endothelial cells.
\end{abstract}

Key words _ bio-organometallics; nuclear factor erythroid 2-related factor 2; copper complex; endothelial cell

\section{1. はじめに}

有機一無機ハイブリッド分子（有機金属化合物・ 金属錯体分子）は，有機化合物に金属を導入したそ の分子構造から，金属と分子構造の相互の活性制御 が可能である，そのため，従来の純粋な無機化合 物・有機化合物ではなし得ない優れた生物活性を持 ち, 創薬のシード/リード化合物及び生体機能解析 研究のツールとしての活用が期待される，われわれ はこの有機-無機ハイブリッド分子のバイオロジー

The authors declare no conflict of interest.

$a$ 東京理科大学薬学部, $b$ 東京理科大学総合研究機構バ イオオルガノメタリクス研究部門（下278-8510 千葉県 野田市山崎 2641), c 名古屋大学物質科学国際研究セン 夕一（广464-8602 名古屋市千種区不老町）, $d$ 東邦大学 薬学部（干274-8510 千葉県船橋市三山 2-2-1), $e$ 筑波 大学大学院人間総合科学研究科（T305-8575 茨城県つ くば市天王台 1-1-1)

*e-mail: t-kaji@rs.noda.tus.ac.jp

本総説は日本薬学会第 133 年会シンポジウム GS-2 で 発表した内容を中心に記述したものである.
をバイオオルガノメタリクスと呼び，その展開を提 唱している.

金属は強力な生物活性を示し, 必須微量元素であ る亜鉛，鉄，銅などは生体内のシグナル伝達に利用 されている，一方，金属，特に非必須性の金属は強 い毒性を示すことがあり，カドミウムやメチル水銀 などは毒性学研究の対象になっている. 金属錯体分 子は，金属と有機化合物の両方の特性を併せ持ち, 例えば「効率的に金属を標的部位に送達させる」こ とで金属の持つ生物活性を制御することを可能にす る. 1) そのため, 金属の高い生物活性を活用し, 戦 略的に金属の生物活性を制御することが可能であれ ば，創薬研究及び生命科学研究への貢献が期待され るが，そのような戦略に基づく報告はほとんどない.

本総説では，有害金属や酸化ストレスに対する防 御機構を担う，転写因子 nuclear factor erythroid 2related factor $2(\mathrm{Nrf} 2)$ 及び生体防御タンパク質メ タロチオネインの発現を誘導するハイブリッド分子 
について概説する。

\section{2. 血管内皮細胞において転写因子 Nrf2 を活性} 化するハイブリッド分子

Nrf2 は解毒化酵素の発現や酸化ストレスに対す る防御遺伝子を制御している転写因子である. Nrf2 による防御遺伝子の発現誘導には, Nrf2 が抗酸化 応答配列 (antioxidant response element; ARE) に結 合することが重要であるとされている. ${ }^{2)}$ 通常 Nrf2 は Kelch-like ECH-associated protein 1 (Keap1) と 結合し抑制的に制御されており，ユビキチン・プロ テアソーム系により分解されている. Keap1 は求電 子性物質に対するセンサータンパク質として機能し ている. 求電子性の毒物や活性酸素種が細胞内へ取 り込まれると，それらはKeap1 タンパク質のシス テイン残基を化学修飾し，そのことによって Nrf2 は Keap1 からの制御を免れ活性化され，毒物に対

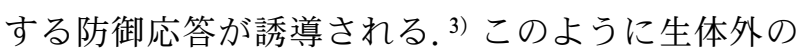
様々な異物やストレスに対する防御機構を制御する Nrf2 は，創薬の標的分子としても期待されてい る。われわれはハイブリッド分子を用いて Nrf2 を 活性化する化合物を探索した。

まずわれわれは，血管内皮細胞における Nrf2 の 活性化を金属錯体分子（15 化合物）から探索した. その結果，血管内皮細胞に傷害を示さず，Nrf2 を 活性化するハイブリッド分子として copper diethyldithiocarbamate $(\mathrm{Cu} 10)$ を見い出した.この $\mathrm{Cu} 10$ による Nrf2 の活性化は代表的な Nrf2 活性化剂で あるスルフォラファンより強力であることが確認さ れた．さらにCu10による Nrf2 の活性化と相関し て，Nrf2 の下流に存在する防御タンパク質の発現 上昇が確認された。 以上より Cu10 は Nrf2 を活性 化し，それにより細胞内防御機能を高めるハイブリ ッド分子であることが示された.

一方, Cu10でみられた Nrf2 の活性化は, 無機 銅イオン及び配位子には認められなかった。また，

$\mathrm{Cu} 10$ の亜鉛置換体及び鉄置換体にも Nrf2 の活性 化能は観察されなかった. Cu10 処理では細胞内へ の銅の高い蓄積が確認された。これに対し，無機銅 イオン, 配位子，亜鉛置換体及び鉄置換体処理で は，それぞれの金属の有意な蓄積は認められなかつ た．以上より，銅錯体 $\mathrm{Cu} 10$ は銅と配位子が錯体分 子を形成することによって血管内皮細胞に速やかに 取り込まれること, またこのような現象は, diethyl- dithiocarbamate 錯体のうち，中心金属として銅が 組み込まれたときに限ることが示唆された.

\section{3. ハイブリッド分子による血管内皮細胞のメタ}

\section{ロチオネインの発現誘導}

メタロチオネインはシステインリッチな低分子量 タンパク質である. メタロチオネインは, カドミウ ムに代表される有害金属の毒性を軽減するだけでな く，抗酸化作用や炎症反応の抑制など，細胞内の防 御タンパク質として重要な役割を果たしている。ささ らには生体内微量元素の恒常性維持にも寄与すると されており，その機能は多岐にわたる。様々な環境 に曝露される血管内皮細胞において，このような多 機能な防御タンパク質の発現は重要であると思われ るが，内皮細胞のメタロチオネイン発現の制御機構 についての詳細は不明な点が多い.4) メタロチオネ インは種々の金属イオンにより発現を誘導される が，金属の非特異的な反応ゆえにその発現誘導機構 を詳細に解析することは困難である. ハイブリッド 分子は，金属の生物活性を制御することが可能であ り，メタロチオネイン発現機構の解析を行う有用な ツールとして活用できると考えられた.

われわれは, Cu10で処理した血管内皮細胞のメ タロチオネイン-1/2 の発現を調べた。その結果, Cu10によりメタロチオネイン-1/2 タンパク質の発 現誘導が確認された。しかしながら，Cu10を構成 する無機銅イオン又は配位子処理では，メタロチオ ネインの発現誘導は確認されなかった。また, メ夕 ロチオネイン各分子種の mRNA 発現を検討したと ころ, Cu10 処理により MT-1A, MT-1E, 及び

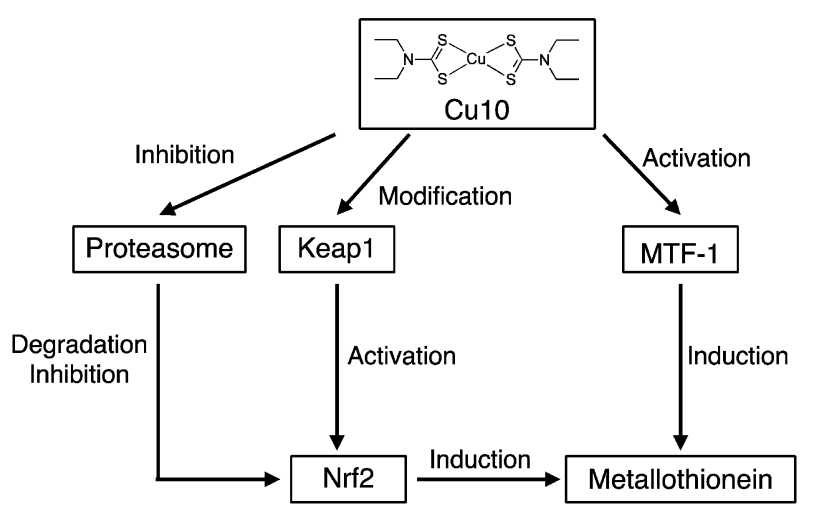

Fig. 1. A Possible Mechanism of Metallothionein Induction by $\mathrm{Cu} 10$ in Vascular Endothelial Cells

Cu10 activates Nrf2 via Keap1 modification and proteasome inhibition in vascular endothelial cells and induces metallothionein via MTF-1 and Nrf2 activation. 
MT-2 の mRNA 発現がすべて上昇していることが 確認された。これらの結果は，銅錯体 Cu10 が錯体 分子としてメタロチオネインの発現を分子種を選択 せずに誘導するハイブリッド分子であることを示し ていた.

次に, メタロチオネインの発現誘導機構について 調べた。メタロチオネインの制御に必須とされる重 金属要求性転写因子（metal-responsive transcription factor-1; MTF-1) 及びメタロチオネイン発現へ の関与が示唆される Nrf2 をノックダウンし, メタ ロチオネイン-1/2 タンパク質の発現を調べた。そ の結果，MTF-1 及び Nrf2 の発現低下に相関して, メタロチオネイン-1/2 タンパク質の発現低下が確 認された。この結果から, 銅錯体 Cu10 は MTF-1 及び Nrf2 が関与する複数の経路を介してメタロチ オネインの発現を誘導することが示唆された（Fig. $1)$.

4. おわりに

本研究において, 転写因子 Nrf2 を活性化しメ夕 ロチオネインを誘導するハイブリッド分子として銅 錯体 Cu10 を見い出した。この生物活性は銅と配位
子が錯体を形成することによりもたらされ，Cu10 はメタロチオネインの発現誘導機構を解析する有用 なツールとしての活用が期待される。本研究の成果 は，有機一無機ハイブリッド分子の生体機能解析 ッールとしての有用性を示しており，ハイブリッド 分子を活用する新しいバイオロジー，バイオオルガ ノメタリクスの展開が期待される.

\section{REFERENCES}

1) Kimura T., Yoshida K., Yamamoto C., Suzuki M., Uno T., Isobe M., Naka H., Yasuike S., Satoh M., Kaji T., Uchiyama M., J. Inorg. Biochem., 117, 140-146 (2012) .

2) Motohashi H., Yamamoto M., Trends Mol. Med., 10, 549-557 (2004).

3) Kobayashi M., Li L., Iwamoto N., NakajimaTakagi Y., Kaneko H., Nakayama Y., Eguchi M., Wada Y., Kumagai Y., Yamamoto M., Antioxid. Redox Signal., 7, 385-394 (2005).

4) Kaji T., Yakugaku Zasshi, 124, 113-120 (2004) . 